International Journal of Advanced Academic Research (Sciences, Technology and Engineering) | ISSN: 2488-9849

Journal DOI: 10.46654/ij.24889849 Vol. 6, Issue 9 (September, 2020) | www.ijaar.org

Article DOI: 10.46654/ij.24889849.e697

\title{
CORROSION BEHAVIOUR OF ANTIMONY MODIFIED CARBIDIC AUSTEMPERED DUCTILE IRON (CADI) IN NEUTRAL ENVIRONMENT
}

\author{
Alao, A.O' ${ }^{1}$ Barnabas, A.A ${ }^{2}$; Momoh, M.I ${ }^{3}$; Omokhafe, M.S ${ }^{2}$; Bankole, R. $^{2}$ and \\ Akinfolarin J. F \\ ${ }^{1}$ Department of Foundry Engineering, Federal Polytechnic, Idah, Kogi State, Nigeria. \\ ${ }^{2}$ Department of Metallurgical and Materials Engineering, Federal University of Technology, \\ Akure, Ondo State, Nigeria. \\ ${ }^{3}$ Foundry Department, Kogi State Polytechnic, Osara, Kogi State, Nigeria.
}

Corresponding author's email: sweetdamse108@gmail.com, barnabelad0110@gmail.com

\begin{abstract}
In this work, effects of antimony on the corrosion behaviour of antimony modified carbidic austempered ductile iron were studied. Rod-like samples (CADI) were produced by sand casting technique in which sandwich method were used to evaluate the influence of austempering temperatures on corrosion behaviour of antimony modified carbidic austempered ductile iron. Six different alloys with equivalent carbon of hyper-eutectic composition (carbon equivalent of 4.44) were used in order to evaluate the effect of antimony contents ranging from 0.096 to $0.48 \%$ at austenitic temperature of $910^{\circ} \mathrm{C}$ and austempering temperatures of $300^{\circ} \mathrm{C}$ and $325{ }^{\circ} \mathrm{C}$ for period of 3hrs. Studying particularly effects of carbide content and graphite shape, besides their stability during the heat treatment with respect to corrosion behaviour of the CADIs. The results show that the microstructures of the as-cast samples mainly consist of few nodular graphite, pearlite and carbides. While the heat-treated samples contain graphite nodules, carbides of varying sizes, ausferrite and retained austenite. As the antimony content increases, corrosion resistance of the carbidic austempered ductile iron increase until critical antimony content is attained. With increase in antimony content, the amount of nodular graphite decreases, pearlite and carbides present increase. As antimony content increases, the acicular ferrite becomes finer, corrosion resistance increased. At austempering temperature of $300^{\circ} \mathrm{C}, \mathrm{CADI}$ sample with antimony content of $0.192 \mathrm{wt} \% \mathrm{Sb}$ has the best corrosion resistance in neutral environment at austempering time of lhour with the least corrosion rate of $6.0234 E$ 07 mmpy. While at austempering temperature of $325^{\circ} \mathrm{C}$, the best corrosion resistance was obtained with the CADI having $0.096 \mathrm{wt}$. \% antimony content held for austempering time of 2 hours (least corrosion rate of 6.6108E-4 mmpy). From the corrosion results obtained, it was observed that the electrochemical behaviour of these CADIs in neutral environment was influenced by antimony content, austempering temperature, and austempering time.
\end{abstract}

Keywords: Carbidic austempered ductile iron; Microstructure; Carbides; Antimony; corrosion, Austempering temperatures of $300^{\circ} \mathrm{C}$ and $325^{\circ} \mathrm{C}$; neutral environment. 


\section{Introduction}

(CADI) is a new class of Austempered Ductile Iron (ADI) containing carbides in the ausferrite matrix. CADI is produced by austempering the carbidic ductile iron at different temperatures and time. It is an economical substitute for wrought or forged steel and has been used more and more in automobile, mining, railway and agricultural machinery sectors(Seshan, 1998). Due to its superior properties over other materials it can also be used in applications like piston rings in internal combustion (IC) engines, dies, gears, navy ship boards, and rollers (Panditl and Patil, 2015). Metallic materials are precious resources of any country, someday there will be an acute shortage of these materials. An impending metal crisis does not seem anywhere to be a remote possibility but a reality. To preserve these valuable resources, we need to understand how these resources are destroyed by corrosion and how they must be preserved by modifying the microstructure of the material for corrosion protection. Corrosion has been a very important factor in these disasters. Applying the knowledge of corrosion protection can minimize such disasters. Prevention would be more practical and achievable than complete elimination. Corrosion processes develop fast after disruption of the protective barrier and are accompanied by a number of reactions that change the composition and properties of both the metal surface and the local environment. For example, formation of oxides, diffusion of metal cations into the coating matrix, local $\mathrm{pH}$ changes, and electrochemical potential. The study of corrosion of cast irons is a matter of tremendous theoretical and practical concern and as such has received a considerable amount of interest (Bouklah, et al., 2005). The problem of metallic corrosion is one of significant proportions: in economic terms, it has been estimated that approximately $5 \%$ of an industrialized nation's income is spent on corrosion prevention, maintenance, replacement, products lost or contaminated as a result of corrosion reactions (Callister, 2001). The aim of this work is to investigate the corrosion behaviour of antimony ( $\mathrm{Sb}$ ) modified CADI in neutral environment as an agricultural implement.

\section{Experimental procedure}

\subsection{Sample preparation}

The material used in this study was obtained in a metal casting laboratory, using a $3 \mathrm{~kg}$ capacity electric arc furnace. Cast iron scrap and foundry returns were used as charge materials. In all cases the melts were nodulized with Fe Si Mg (9 wt. \% Mg) and inoculated with Fe-Si (75 wt. \% Si). Six alloys of ductile iron were obtained, with approximately 0, 0.096, 0.192, 0.288, 0.384 and $0.48 \mathrm{wt}$. \% Sb. The dimension of each sample cast is $20 \mathrm{~mm}$ by $20 \mathrm{~mm}$ by $200 \mathrm{~mm}$.

The rods were cut longitudinal into $20 \mathrm{~mm} \times 30 \mathrm{~mm}$ long for the microstructural characterisation, $10 \mathrm{~mm}$ thick $\times 50 \mathrm{~mm}$ long for impact and $20 \mathrm{~mm} \times 40 \mathrm{~mm}$ for wear test samples. Hardness measurements were also performed on all the samples of dimensions $20 \mathrm{~mm}$ x $25 \mathrm{~mm}$.

The samples obtained from the five alloys were then heat-treated by austenitizing at $910 \circ \mathrm{C}$ and held for 1 hour in a muffle furnace followed by an austempering step in a sodium nitrate potassium nitrate salt bath at temperature $300{ }^{\circ} \mathrm{C}$ and $325^{\circ} \mathrm{C}$ at different time of $1-3 \mathrm{hrs}$. The 
unalloyed samples without antimony (conventional CADI) were used as reference material for wear and impact tests together with the CADI variants (having different antimony contents).

\subsection{Chemical and microstructural examination}

The chemical composition of the alloys was determined by means of a Spark Emission Optic Spectrometer with a DV6 excitation source. The chemical composition of the carbides was evaluated by using a FESEM Scanning Electron Microscope with an EDX module, in order to analyse the micro-segregation effects and its influence on the carbide dissolution during heat treatment. The values reported are the average of five determinations.

Metallographic sample preparation for optical microscopy examination was carried out by using standard techniques for cutting, grinding and polishing before etching with $2 \% \mathrm{Nital}$.

Corrosion test was conducted using potentiodynamic polarization electrochemical methods in accordance with ASTM G57-97 (2014) standard. The experiment was carried out using Versa Potentiostat. Corrosion behaviour of the samples was investigated in neutral and chloride environment at ambient temperature $\left(25{ }^{\circ} \mathrm{C}\right)$. Potentiodynamic polarization measurement was carried out using a scan rate of $0.1666 \mathrm{mV} / \mathrm{s}$ at a potential initiated at $-200 \mathrm{mV}$ to $+250 \mathrm{mV}$. Two repeat tests were carried out for all compositions of the alloys, and the reproducibility and repeatability were observed to be reasonably good as there were no significant differences between results from duplicates. Corrosion rate was calculated using both penetration rate (C.R) and mass loss rate (M.R) of Faraday's law of corrosion (Barnartt, 1977). The equations stated below according to Mansfeld, 1972 were used to calculate both the penetration rate (C.R) and mass reduction rates (M.R) as in expressions 1 and 2.

$$
\text { C.R }=\underline{\text { Ki x Icorr x EW }}
$$

a

$$
\text { M. } \mathrm{R}=(\mathrm{K} 2 \mathrm{x} \text { Icor } \mathrm{x} \mathrm{Ew})
$$

C.R is given in $\mathrm{mm} / \mathrm{yr}, \mathrm{I}_{\mathrm{corr}}\left(\mu \mathrm{A} / \mathrm{cm}^{2}\right)$

$\mathrm{Ki}=3.27 \times 10-3(\mathrm{mmg} / \mu \mathrm{A} \mathrm{cm} \mathrm{yr})$

$\mathrm{K} 2=0.008954$

M.R is given in $\mathrm{g} / \mathrm{m}^{2} \mathrm{~d}, \mathrm{EW}$ is equivalent weight of 27.9

\section{Electrochemical Investigation}

Electrochemical experiments were performed on the samples in a neutral environment by means of Versa-Stat interfaced with computer using potentio-dynamic technique. The cell contained a platinum disc as counter electrode, a saturated calomel electrode as reference and the working electrode (with and without antimony modified carbidic austempered ductile iron). Before every run, the surface of the specimens of area $1 \mathrm{~cm}^{2}$ was polished using emery paper of 60 and 
400 grits. The potential scanning rate was $1 \mathrm{mV} / \mathrm{min}$ at $-250 \mathrm{mV}$ to $250 \mathrm{mV}$. All potentials are reported with respect to the saturated calomel electrode. The experiment was done at ambient temperature. The polarization curves were performed on the cast samples and heat treated samples in neutral environment.

\section{Results and discussion}

\subsection{Chemical and microstructural characterization}

Table 1: Chemical Composition of the produced Alloys (wt. \%)

\begin{tabular}{lllllllllllll}
\hline & Fe & C & Si & Mn & Cr & Ni & Cu & Mg & Sb & S & P & C.E \\
No & & & & & & & & & & & & \\
\hline $\mathbf{1}$ & 89.39 & 3.62 & 2.42 & 0.58 & 2.6 & 0.60 & 0.69 & 0.06 & - & 0.004 & 0.040 & 4.43 \\
$\mathbf{2}$ & 89.33 & 3.62 & 2.40 & 0.57 & 2.61 & 0.61 & 0.65 & 0.07 & 0.096 & 0.005 & 0.041 & 4.43 \\
$\mathbf{3}$ & 89.24 & 3.62 & 2.41 & 0.57 & 2.62 & 0.62 & 0.61 & 0.07 & 0.192 & 0.005 & 0.042 & 4.44 \\
$\mathbf{4}$ & 89.19 & 3.63 & 2.40 & 0.56 & 2.60 & 0.60 & 0.62 & 0.07 & 0.288 & 0.005 & 0.042 & 4.44 \\
$\mathbf{5}$ & 89.10 & 3.62 & 2.41 & 0.56 & 2.63 & 0.61 & 0.62 & 0.06 & 0.384 & 0.005 & 0.040 & 4.44 \\
$\mathbf{6}$ & 88.97 & 3.62 & 2.40 & 0.58 & 2.62 & 0.60 & 0.63 & 0.06 & 0.480 & 0.004 & 0.041 & 4.43 \\
\hline & & & & & & & & & & &
\end{tabular}


Sterographs of the Corroded Surfaces of the Produced Samples

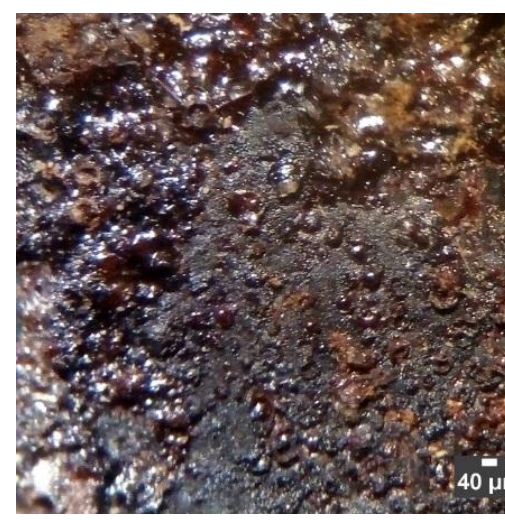

Plate 1:unmodified CADI

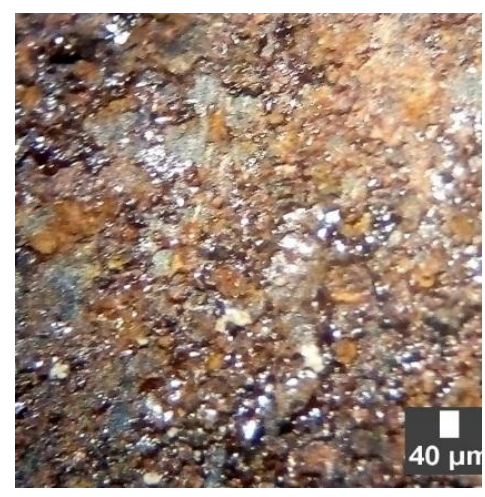

Plate 2: modified CADI

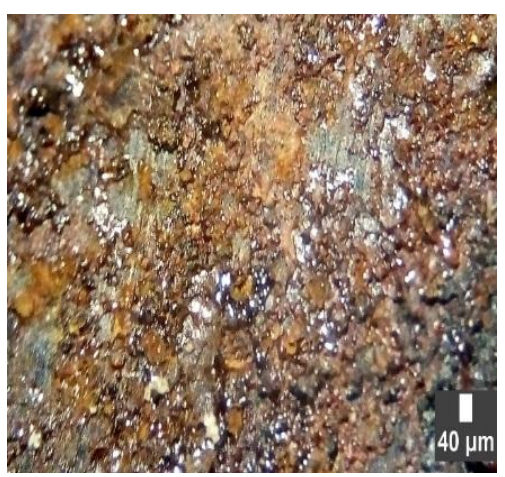

Plate 3: modified CADI

SEM (S.E) Photographs of the Corroded Surfaces of the Produced Samples

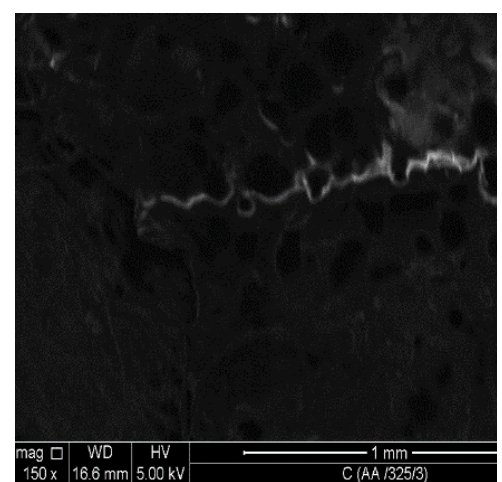

Plate 4:unmodified CADI

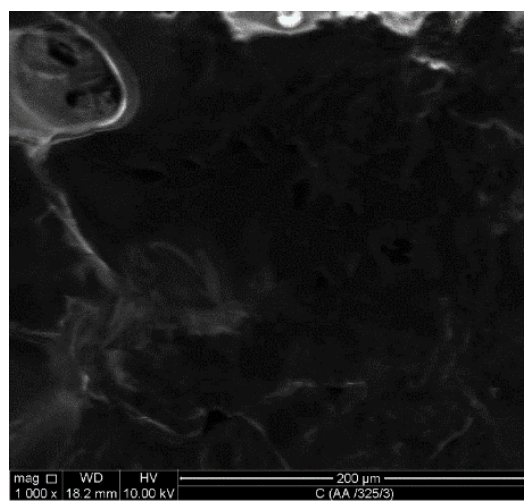

Plate 5: modified CADI

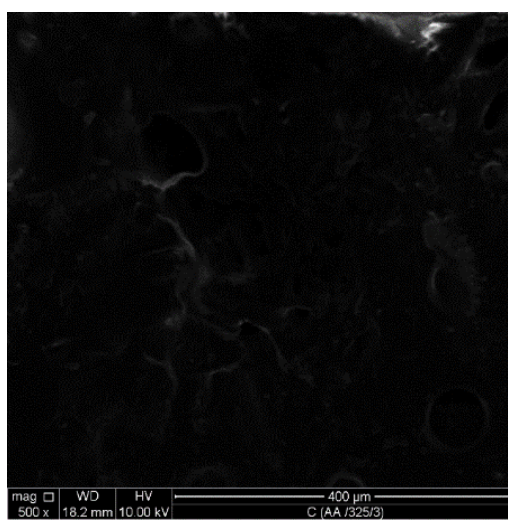

Plate 6: modified CADI 


\section{Stereographic View of the Corroded Surfaces of the Produced CADI}

Changes in the appearance and colour of the corrosion products formed on the surface of the produced cast samples were examined using stereo microscope (Plates 1 - 3). As seen from Plates $(4-6)$, the general appearance of the surface corrosion products was similar for all the produced CADI samples, the specimen exposed in static water formed on adhering corrosion produced without sign of delamination from the surface (Plates 4 - 6).

The produced CADI samples exposed to static water, show an initial layer of adherent, red oxide formed on the surface and covered substantial portion of the surface.

From Plates $4-6$, it can be seen that the general corrosion is the primary type of degradation that took place, localized corrosion seems to be minor form of surface degradation on the samples.

Corrosion current and rates results obtained from open circuit potential (OCP) monitoring of the specimens are shown in Figure 1. From which it can be seen that the OCP for specimens exposed to static well water experiment, it moves toward less positive (more anodic),

\section{Electrochemical Behavior}

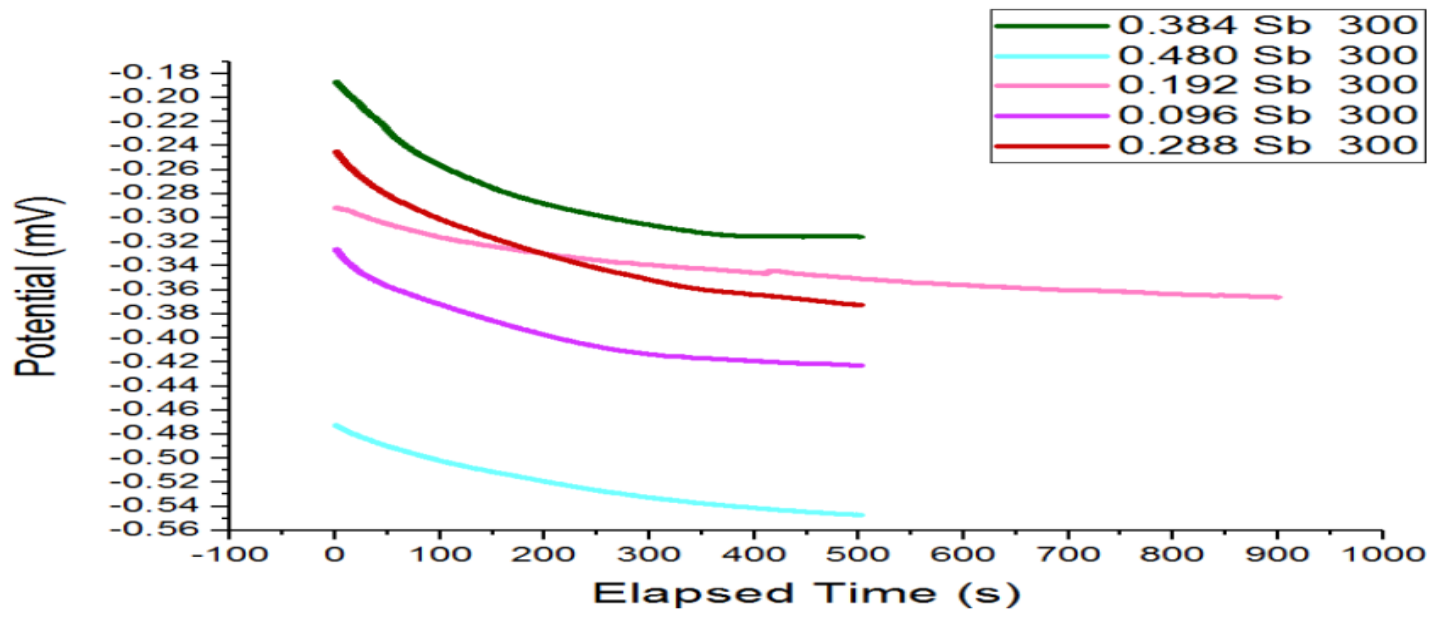

Figure 1: Open Circuit potential of the Produced Samples against Elapsed Time 


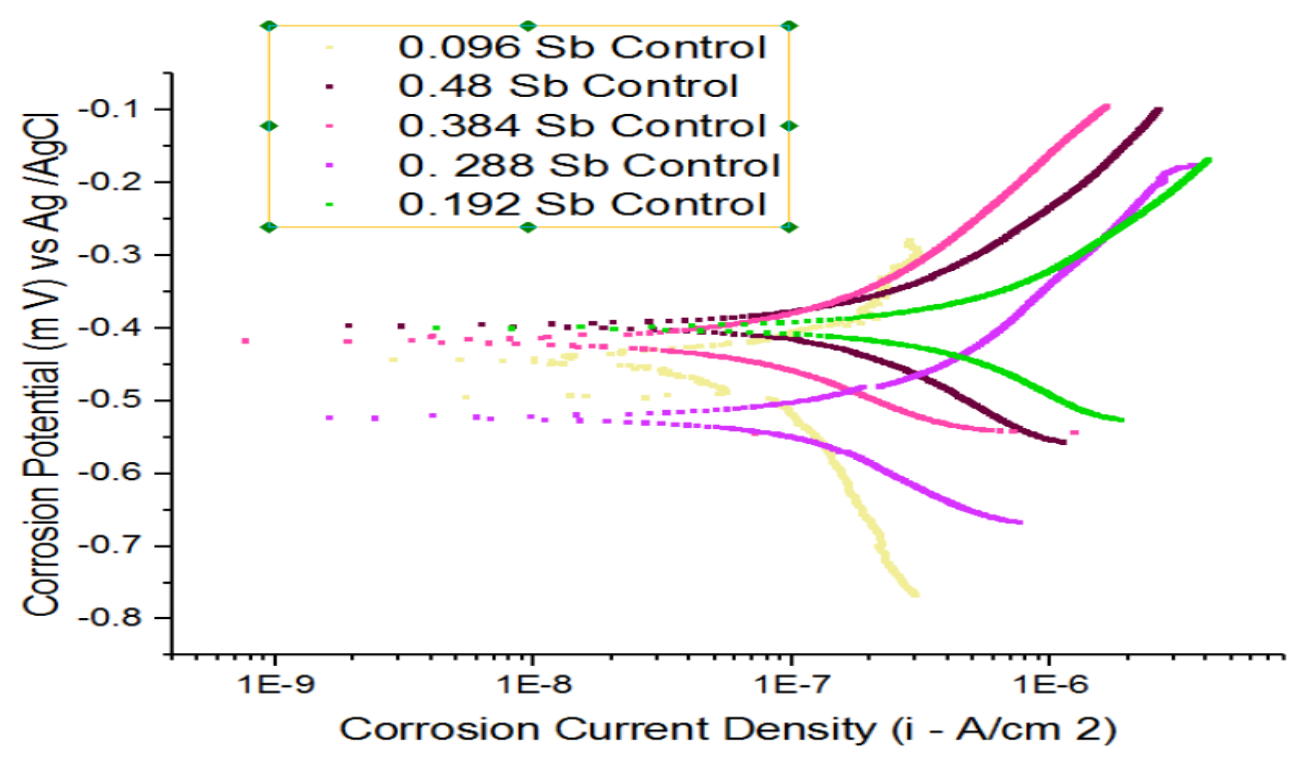

Figure 2: Corrosion Potential of the Unheated Treated Produced Samples against Elapsed Time

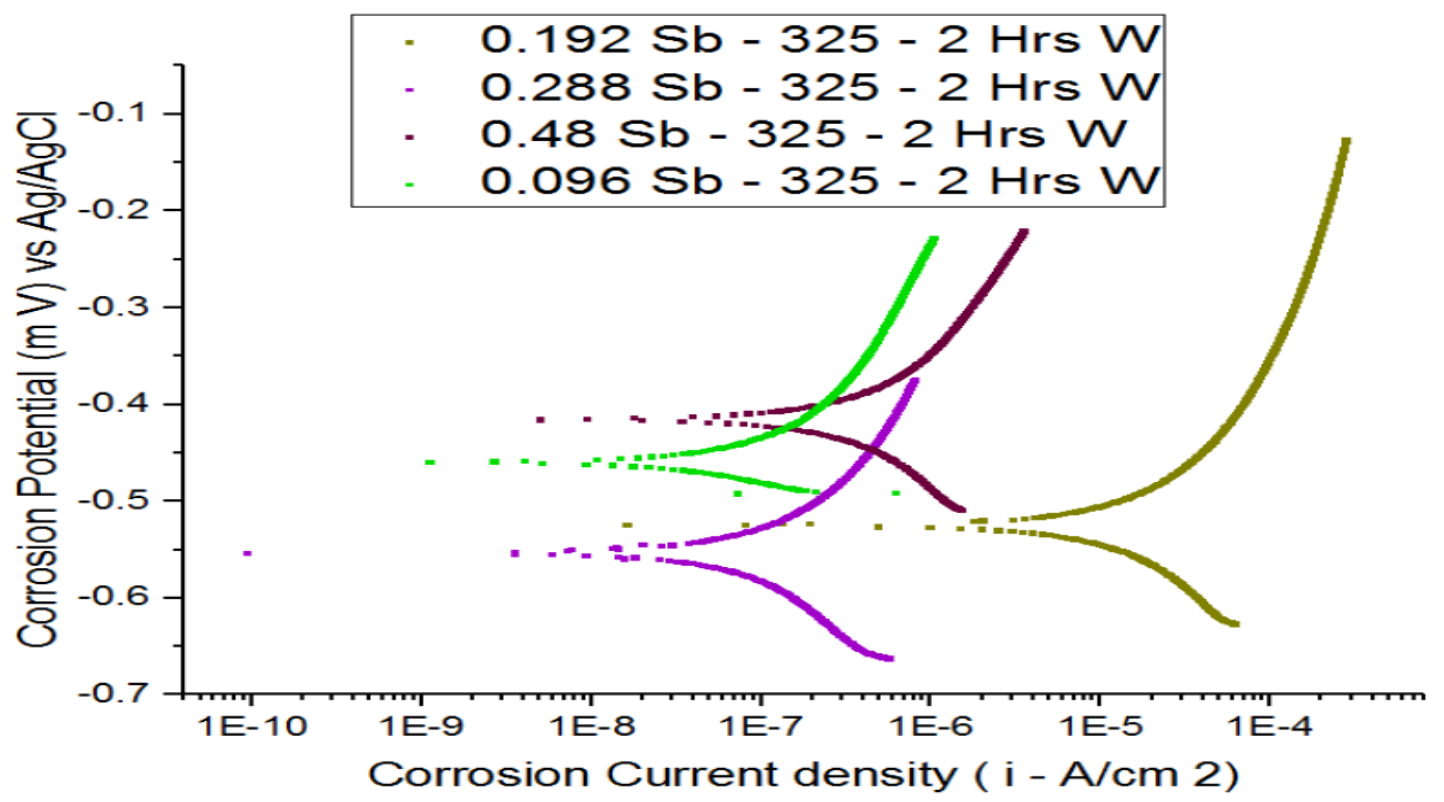

Figure 3: Corrosion Potential of the Heat Treated Samples against Elapsed Time 


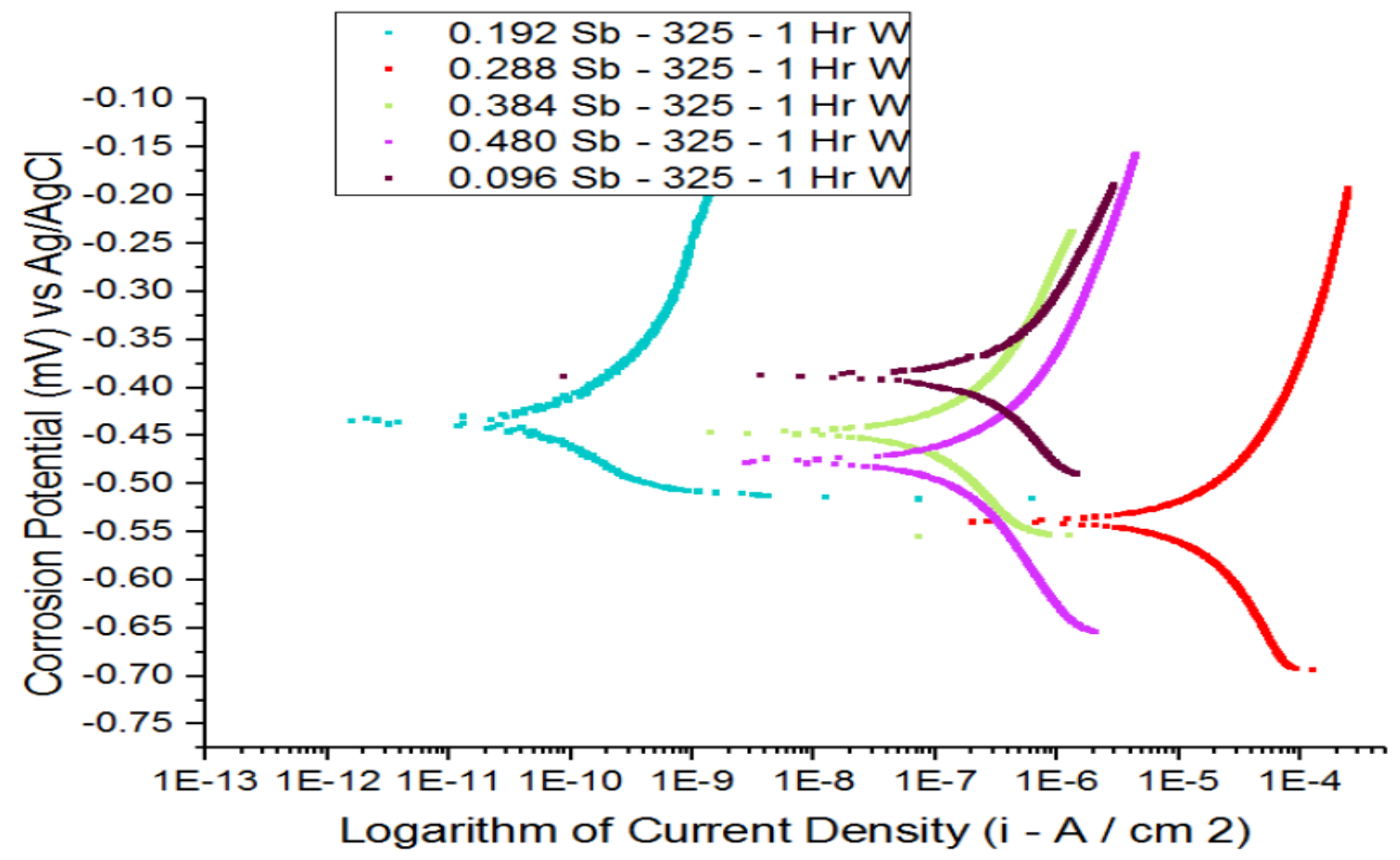

Figure 4: Corrosion Potential of the Produced Samples against Elapsed Time

Among the carbidic ductile irons (CDI) containing antimony content ranging from $0.096 \mathrm{wt}$. \%, 0.192 wt. $\%, 0.288$ wt. $\%, 0.384$ wt. $\%$ and 0.48 wt. $\%$ produced without heat treatment, CDI with antimony content of 0.384 wt. \% has the highest open circuit potential value and consequently the least corrosion rate value, signifying the positive influence of antimony on the produced CDI (Venkatesan et al., 2002).

Figures $(1-4)$ show that the CADI generally displayed similar polarization curves and passivity characteristics. It was observed that CADIs with $0.384 \mathrm{wt}$. \% Sb has the lowest corrosion rate of 0.00068907 mmpy compare with CADIs with 0.096 wt. \% Sb (0.015782 mmpy), 0.288 wt. \% $\mathrm{Sb}(0.002735 \mathrm{mmpy})$, and 0.48 wt.\% Sb (0.62568 mmpy). Correspondingly, the produced CADI with 0.384 wt. \% Sb has the least corrosion current density of $-59.383 \mathrm{nA}$ and the highest corrosion potential of $-518.205 \mathrm{mV}$ compared with samples with $0.096 \mathrm{wt}$.\% Sb $(1.36 \mu \mathrm{A}$ and $728.002 \mathrm{mV}), 0.288$ wt.\% $\mathrm{Sb}(-235.707 \mathrm{nA}$ and $-530.657 \mathrm{mV})$, and $0.48 \mathrm{wt} . \% \mathrm{Sb}(-53.921 \mu \mathrm{A}$ and $-532.496 \mathrm{mV}$ ). From the above corrosion parameters obtained from the electrochemical test, it was discovered that CADI sample with $0.384 \mathrm{wt}$. \% Sb has the best corrosion resistance hence it has the least corrosion current density, lowest corrosion rate and the highest corrosion potential. It was also observed that there was a progressive increase in corrosion resistance with increase in the antimony content until a critical content of $0.384 \mathrm{wt} \%$ was reached beyond which the corrosion resistance reduced significantly. It is observed that there was an appreciable increase in the corrosion resistance of the samples subjected to austempering heat-treatment 
operations compared with the as-cast samples. Among the samples subjected to austempering temperature of $300{ }^{\circ} \mathrm{C}$ with austempering time of 1hour, the least corrosion rate of 0.0000060234 mmpy for CADI with 0.192 wt. \% Sb was obtained, suggesting that at austempering time of 1 hour, CADI with 0.192 wt. \% has the best corrosion resistance. At austempering time of 2 hours, CADI sample with 0.192 wt. \% still has the best corrosion resistance. For the austempering time of 3hours, CADI with 0.384 wt. \% Sb has the least corrosion rate of $0.0014806 \mathrm{mmpy}$, current density of $-127.595 \mathrm{nA}$ and corrosion potential of $369.563 \mathrm{mV}$ at the austempering temperature of $300{ }^{\circ} \mathrm{C}$. Graphitic corrosion normally observed in grey cast iron as a result of selective leaching of the cast iron in water that leave graphite network was not observed in this case.

The surface of the samples was uniformly covered with corrosion products and no fouling was seen (Schumacher, 1979 and Shreir, 1984). The severe corrosion usually experienced by austempered ductile iron as result of carbide was reduced by the antimony element judging from the corrosion rate values (Beccaria, 1995). It was very clear that for most of the CADI, use of micro - quantity of antimony element does not degrade the corrosion properties of the CADI in well water. 


\section{CONCLUSION}

1. Electrochemical behaviour of antimony modified CADI in neutral environment has been studied.

2. Stereo - micrographs of the corroded surface of the produced samples was taken which revealed that similar general corrosion appearance was formed on the samples

3. Reddish and adherent oxide was seen on the substantial portion of the stereo-graphs of the samples

4. Open Circuit Potential of the CADI immersed in well water moves towards less positive potential.

5. Among the produced Carbidic Ductile Iron (CDI) samples immersed in well water, the sample with antimony content of 0.384 wt.\% has the lowest current density, corrosion rate and the highest corrosion resistance.

6. CADI sample (heat treated CDI) with antimony content of $0.192 \mathrm{wt} \%$ has the least corrosion rate and consequently the best corrosion resistance.

7. No graphitic corrosion was observed in the samples

8. Generally, it can be summarized that the CADI samples with antimony additions displayed better corrosion resistance compared to CADI without antimony additions. This shows that antimony element has been able to modify to CADI samples to the extent of reducing the susceptibility carbide induce corrosion usually experienced in cast irons with high carbide content. 


\section{REFERENCES}

Barnartt, S. (1977): Electrochemical Nature of Corrosion, Electrochemical Techniques for Corrosion, Baboian Edition, National Association of Corrosion Engineers, Houston, Pp $1-10$.

Beccaria, A. M., Poggi, A. M. and Castello, G. (1995): Brazil Corrosion Journal, Vol. 30, Issue 4, Pp 283-299.

Callister, W. D. (2001): Fundamentals of Materials Science and Engineering. John Wiley and Sons, Incorporation, New York. Pp 69-185.

Mansfield, F. (1972): Tafel Slopes and Corrosion Rates from Polarization Resistance Measurements, Corrosion, Vol. 29, P 10.

Pandit, P. L. and Patil, S. A. (2013): Effect of Wire Electrical Discharge Machine, Parameters on Material Reduction Rate of Carbidic Austempered Ductile Iron, International Journal of Science and Research (IJSR) ISSN (Online): 2319 -7064 Index Copernicus Value, Pp 6

Schumacher, M. (1979): 'Sea Water Corrosion Handbook', Pp107 - 964; New Jersey, Noyes Data.

Seshan, S. (1998): Austempered Ductile Iron - The Under Exploited Wonder Cast Iron, Indian Foundry Journal, Pp. 84 - 92.

Shreir, I. I. (1984): ‘Corrosion', Pp 4 -20: Vol.1; London, News Butterworths.

Venkatesan, R., Venkatasamy, T. A., Bhaskaran, T. A, Dwarakadasa E.S, Dwarakadasa and Ravindran, M. (2002): Corrosion of Ferrous Alloys in Deep Sea Environments: The Institute of Materials, Minerals and Mining, British Corrosion Journal, Vol. 37, No. 4, Pp 261 - 263, Issue 257. 